\title{
A Rare Cause of Neck Mass: Pilomatrixoma
}

\author{
(1) Caner Turan, (1) Ali Yurtseven, (1) Eylem Ulaş Saz
}

Ege University Faculty of Medicine, Department of Pediatrics, Division of Pediatric Emergency, İzmir, Turkey

\begin{abstract}
Pilomatrixoma (pilomatricoma) (Malherbe's calcifying epithelioma), although rare, is the second most frequent benign skin tumour in childhood. It originates from the hair follicles. It is most commonly seen on the head and in the neck region, it also may be located on the upper extremities. Diagnosis may be confused with other skin tumours and malignancies. In this case, we report on a patient who presented with a mass on the neck diagnosed as a pilomatrixoma.

Keywords: Pilomatricoma, pilomatrixoma, skin tumour, child
\end{abstract}

\section{Introduction}

Pilomatrixoma is a benign tumour of the skin which originates from the cortex of hair follicles and is named as "calcifying epithelioma". Although rare, it is the second most common benign tumour of the head and neck, which are its most common locations. The majority of cases occur in the first two decades of life. It is a dermal tumour which is generally a well-demarcated, hard, mobile superficial nodule that grows slowly and it rarely shows malign transformation. In this case, we report on a patient who presented with a mass on the neck diagnosed as a pilomatrixoma.

\section{Case Report}

A 7-year old boy was admitted to the pediatric emergency department because of a swelling on the left side of the neck. It was first noticed four months previously, grew increasingly and did not respond to antibiotic treatment. He did not have fever, anorexia, sweating or weight loss in his history. On physical examination, a palpable pea-sized mass, approximately $20 \times 10 \mathrm{~mm}$ in size, was noted in the left posterior cervical region. The mass was mobile, hard and well-demarcated (Figure 1, 2). Lymphadenopathy (LAP) was not present. Further physical examination was normal. According to laboratory findings, hemogram, peripheral smear, erythrocyte sedimentation rate and other biochemical tests were normal, C-reactive protein was negative, serologic analyses were normal, toxocara immunoglobulin (Ig) $M$ and toxoplasma IgM-IgG were negative. Ultrasound examination showed a solid mass, $14 \times 9 \mathrm{~mm}$ in size, on the left posterior cervical region and no organomegaly in the abdomen. The purified protein derivative (PPD) of tuberculin test was normal ( $3 \mathrm{~mm}$ ). A local excision of the mass was performed. Gross examination of the specimen showed a $20 \times 50 \times 10$ $\mathrm{mm}$ firm white nodule with a calcified cut surface and capsule. Pilomatrixoma was diagnosed with the appearance of basaloid hair matrix cells and eosinophilic anucleated shadow cells under histologic examination. The patient's recovery was uneventful. No malign transformation was observed and no recurrence was seen after a follow-up period of 8 months. Verbal consent was given by the patient's parents. 


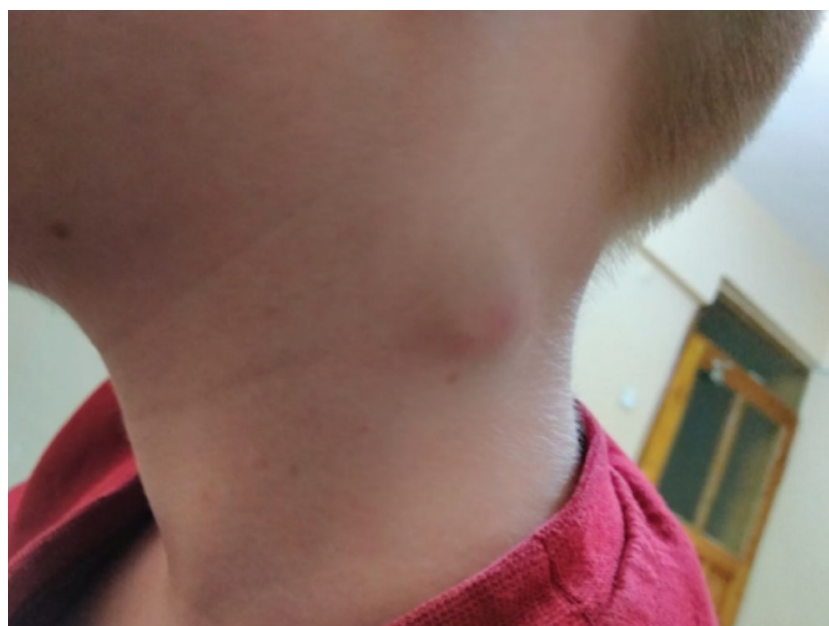

Figure 1. A palpable pea-sized mass, approximately $20 \times 10 \mathrm{~mm}$ in size, in the left posterior cervical region

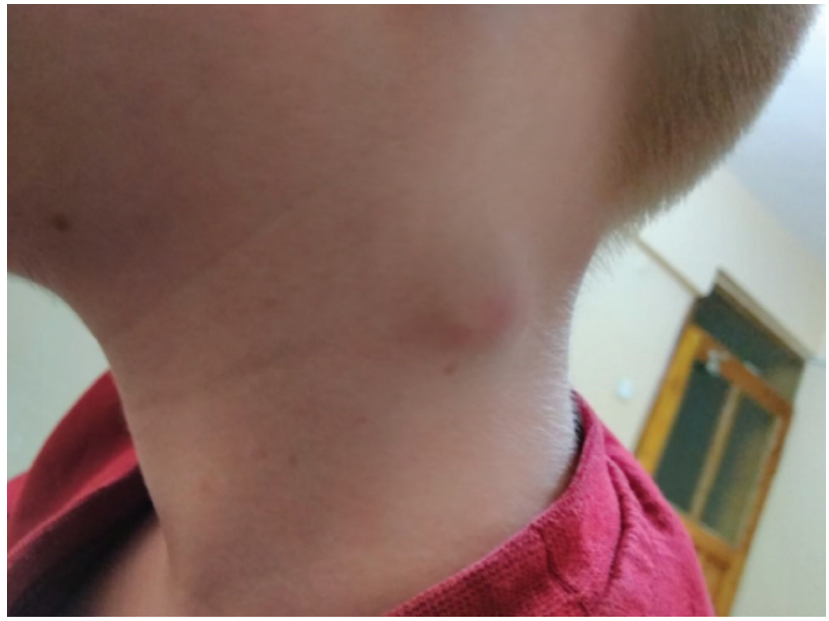

Figure 2. A palpable pea-sized mass, approximately $20 \times 10 \mathrm{~mm}$ in size, in the left posterior cervical region

\section{Result}

Pilomatrixoma is a rare benign skin tumour. Despite being well known by dermatologists and pathologists, it causes diagnostic difficulties for pediatricians since it is rarely encountered in pediatrics. Rather than requiring a large number of laboratory tests in patients with chronic-subacute LAP, excision after clinical examination will facilitate diagnosis and avoid unnecessary further testing.

\section{Discussion}

LAP is usually benign in childhood with a common prevalence. Aggressive management or biopsy in due time is the most important factor to avoid serious or specific diseases. In children, the most common causes are infections of viruses, bacteria or mycobacteria. Acute localized lymphadenitis may have unilateral or bilateral LAP. In our case, fever, tenderness and fluctuance were not detected. Staphylococcus or group A beta hemolytic streptococci are frequently seen in etiologies $(1,2)$. Also, tooth decay or anaerobic microorganisms in periodontal diseases cause LAPs (1). No tooth decay or history were noted in our patient. Subacute-chronic lymphadenitis is a lymph node that grows in days and weeks, painless or mildly painful, with no fever, sometimes fluctuating and usually without prodromal findings. Mycobacterial infections, cat scratch diseases, cytomegalovirus (CMV), toxoplasmosis-toxin infections, human immunodeficiency virus (HIV), sarcoidosis are considered during the differential diagnosis, but less frequently neoplasms should also be considered. Tuberculous lymphadenitis has unilateral, painless LAP and fistulisation is seen very commonly. Positive $\mathrm{X}$-ray findings have been found in $30-70 \%$ of cases and the existence of a PPD over $15 \mathrm{~mm}$ is consistent with tuberculosis $(1,2)$. In our case, since the fistula was absent, the chest X-ray was normal and PPD was $3 \mathrm{~mm}$; tuberculosis was not considered. In addition, CMV, HIV toxoplasma and toxocara tests were found to be negative in the serological analyses. Cat scratch disease is seen as a self-limited localized LAP caused by Bartonella henselae after contact with cat litter or scratching. In this case, the LAP grows at the bite/scratch site 1-8 weeks after infection and clinical findings of anonymous fever, encephalitis, neuroretinitis, granulomatous conjunctivitis, hepatosplenic involvement, atypical pneumonia and thrombocytopenic purpura may be seen $(3,4)$. In our case, cat scratch disease was not considered because there was no incident of cat contact. Childhood neoplastic (malignant) diseases are also among the causes of LAP. In particular, leukaemia, Hodgkin's disease, non-Hodgkin's lymphoma, solid tumour metastases (neuroblastoma, nasopharyngeal carcinoma, rhabdomyosarcoma and thyroid cancers), histiocytosis (langerhans cell histiocytosis, Haemophagocytic syndromes) should be kept in mind for differential diagnosis (5). In our case, the absence of symptoms B, no malignancy findings in the physical examination and the findings of the laboratory examination results being normal, it was decided to perform a lymph node biopsy for a definitive diagnosis. Neoplastic diseases were not considered. Pilomatrixoma is a rare benign tumour of childhood which frequently develops from the hair follicles of subepidermal tissue (6). They are usually asymptomatic and patients often present with only a solitary, firm mass that grows slowly under the skin (7). While a typical single lesion of $0.5-3 \mathrm{~cm}$ in size is typically seen, large size lesions and a number of familial lesions have also been reported $(6,8)$. Gardner's syndrome may be seen with familial adenomatous polyposis, myotonic muscular dystrophy and Turner's syndrome $(9,10)$. In our case, a unilateral, solitary $2 \times 1 \mathrm{~cm}$ mass was seen similar to cases reported in the literature and also no accompanying syndrome or anomaly were detected. The patient's history and physical findings 
gave rise to thoughts of pilomatrixoma; however, according to the literature, less than $50 \%$ of cases are thought to be pilomatrixoma before a pathological diagnosis is made (11). In our case, a lymph node biopsy was performed to eliminate the possibility of the existence of malignancy due to the history and physical examination findings and the diagnose was set after the histopathologic evaluation. A well-defined solid mass that is localized in the dermis and subcutaneous fat tissue, as seen with ultrasonography (USG), which causes focal scarring in the dermis is typical for pilomatrixoma. A target lesion can be seen in the centre. An acoustic shadow is observed due to calcification in the central nidus (6). However, in our case, the mass was interpreted via USC as only a smoothly bounded solid mass in the subcutaneous area. The reason for not considering pilomatrixoma during USG is thought to be because the differential diagnosis report in which pilomatrixoma was considered was not presented by the patient to the radiologist. Treatment is usually set as surgical excision and rare recurrence may be seen in incomplete excision (11). Malign pilomatrixomas are very rare and mostly seen in adults (12). Total excision was performed in our case and no recurrence was detected in the follow-up period of 8 months.

\section{Ethics}

Informed Consent: Verbal consent was given by the patient's parents.

Peer-review: Externally peer-reviewed.

\section{Authorship Contributions}

Surgical and Medical Practices: C.T., A.Y., Concept: C.T., E.U.S., Design: C.T., E.U.S., Data Collection and Processing: C.T., A.Y., Analysis and Interpretation: C.T., E.U.S., Literature Search: C.T., E.U.S., Writing: C.T., E.U.S.

Conflict of Interest: No conflict of interest was declared by the authors.
Financial Disclosure: The authors declared that this study received no financial support.

\section{References}

1. Ancliff P, Hann I. Lymphadenopathy. In: Richard H. Sills, ed. Practical algorithms in pediatric hematology and oncology. Basel, Reinhardt, 2003: 47-9.

2. Twist Cl, Link MP. Assesment of lymphadenopathy in children. Ped North of America 2002; 49:1009-25.

3. Chung JY, Han TH, Kim BN, Yoo YS, Lim SJ. Detection of bartonella henselae DNA by polymerase chain reaction in a patient with cat scratch disease: a case report. J Korean Med Sci 2005; 20:888-91.

4. Eroğlu C, Çandır N, Dervişoğlu A, Kefeli M. Kedi tırmığı hastalığı olgusu. Mikrobiyol Bül 2007; 41:603-6.

5. Link MP, Donaldson SS. The lymphomas and lymphadenopathy In: Nathan and Oski's Hematology of Infancy and childhood. 6th ed. Philadelphia: WB Saunders, 2003: 1192-96.

6. Kwon D, Grekov K, Krishnan M, Dyleski R. Characteristics of pilomatrixoma in children: a review of 137 patients. Int J Pediatr Otorhinolaryngol 2014; 78:1337-41.

7. Duflo S, Nicollas R, Roman S, Magalon G, Triglia JM. Pilomatrixoma of the head and neck in children: a study of 38 cases and a review of the literature. Arch Otolaryngol Head Neck Surg 1998; 124:1239-42.

8. Guinot-Moya R, Valmaseda-Castellon E, Berini-Aytes L, GayEscoda C. Pilomatrixoma. Review of 205 cases. Med Oral Patol Oral Cir Bucal. 2011; 16:e552-5.

9. Hughes I, Lam A, Rogers M. Use of ultrasonography in the diagnosis of childhood pilomatrixoma. Pediatr Dermatol 1999; 16:341-4.

10. Kovacic M, Rudic M, Nekic l, et al. Giant pilomatrixoma (benign calcifying epithelioma of Malherbe) of the neck and face. Dermatol Surg 2007; 33:340-3.

11. Baykal C. Dermatoloji Atlası. 1. Baskı. İstanbul, ARGOS iletişim Hizmetleri Reklamcılık ve Ticaret A.Ş., 2000; 393.

12. Hassan SF, Stephens E, Fallon SC, et al. Characterizing pilomatricomas in children: a single institution experience. J Pediatr Surg 2013; 48:1551-6. 